\title{
Physiological Maturity of Corn Seeds (Zea mays) by Tetrazolium Salt
}

\author{
Luiz Felipe Nicoleti Torrezan and Ana Dionisia da Luz Coelho Novembre \\ The Department of Agriculture, University of Sao Paulo, Piracicaba 13418-900, Brazil
}

\begin{abstract}
The purpose of this study was to evaluate the relationship of tetrazolium salt testing to common indicators (milk line, black layer, dry matter) used to determine corn seed physiological maturity. The seeds used were the hybrids Pioneer 4285 and Dow 2B587. These hybrids were harvested 40 days after polinization (DAP), with 4-day intervals until 68 DAP. The harvested seeds were evaluated for viability and vigor (germination test, accelerated aging test and cold test). The parameters used to determine the physiological seed's maturity were the black layer, the milk line, the seed dry matter, seed water content and the evaluation of seed tissues using the tetrazolium salt to evaluate the endosperm cells. The germination of both materials was greater than $95 \%$ and there was no difference between harvest times. Corn seed physiological maturity (PM) was identified at 56 DAP for P4285 (F2) and between 48 and 56 DAP for 2B587 (F2). The maximum vigor was detected by accelerated aging tests and cold tests before PM for the two genotypes. The activity of endosperm cells is related to the other PM indicators (milk line, black layer, dry matter and water content). The transport of nutrients from plant to the seed ceases at seed physiological maturity. Use of tetrazolium salt allows identifying cell death of the basal region and this parameter corresponds to the others evaluated, thus demonstrating that the tetrazolium salt is effective for corn seed physiological maturity characterization.
\end{abstract}

Key words: Formation, seed production, seed viability, black layer, milk line, corn seed vigor, corn seed germination.

\section{Introduction}

Prediction of physiological maturity is essential to determine the seed harvest time. Since 1950 many investigators have been working with different methodologies and species. In corn some techniques were developed such as: black layer and milk line [1]. But never before the tetrazolium salt was used with this propose.

The first attempt to identify the physiological maturity (PM) in corn was determining the point crop at which the seed has the maximum dry matter (DM) [2]. This method was later improved by adding a parameter called the black layer which is a thin layer in the kernel basal area that develops simultaneously to physiological maturity [3]. Other researchers also studied the black layer and added information about

Corresponding author: Luiz Felipe Nicoleti Torrezan, MSc, research field: seed technology; Ana Dionisia da Luz Coelho Novembre, PhD, professor, research fields: seed technology, seed analysis, seed. the correlation between seed water content, dry matter, period of formation and environmental influence [3-8]. Following, researchers related the solidification of the endosperm through the seed from the top to the base and created a new parameter, the milk line [9]. The description of the milk line was described in 5 stages and correlated to the black layer, seed water content and dry matter [1].

As physiological maturity was conceptualized, the research moved through the seed quality and the relationship between seed quality and PM. The best values of germination and seed vigor (accelerated aging, cold test and electrical conductivity) were found between stages 3 and 4 of the milk line and black layer $[1,10]$. In addition, more tests were conducted relating indicators of the PM (black layer, milk line) to seed vigor (cold test and conductivity) over a wide range of genotypes and environments. The conclusion was that maximum seed vigor can be reached at different times for single cross, double 
cross and inbred [11].

Several tests are used to determine corn seed vigor and quality. The tetrazolium salt test is one of these. In others areas like medicine and microbiology the tetrazolium salt is utilized to check cell development $[12,13]$. The tetrazolium salt was discovered and used in 1940 by Professor Lakon who worked with cereals such as corn $[14,15]$. Recently the tetrazolium became a normal seed vigor test approved by International Seed Testing Association (ISTA) and Dr. Robert P Moore published more than 230 papers with a wide range of species [16]. However, in the tetrazolium salt any reference literature was not found about the tetrazolium salt and seed physiological maturity.

This way, the objective of this investigation was to identify the correlation of tetrazolium salt activity to the physiological maturity by using these parameters: black layer, milk line, dry matter and seed water content. The behavior of seed germination and vigor during maturation were also evaluated.

\section{Material and Methods}

\subsection{Experimental Conditions}

The research was developed on the campus "Luiz de Queiroz" at the University of Sao Paulo (USP-ESALQ), located in Piracicaba, state of Sao Paulo, Brazil, coordinates $22^{\circ} 43^{\prime} 14^{\prime \prime} \mathrm{S}$ and $47^{\circ} 38^{\prime} 46^{\prime \prime}$ $\mathrm{W}$ at $546 \mathrm{~m}$ of altitude, according Köpper-Geiger climate classification is CWA (warm summer and dry winter) the average temperature of $21.6{ }^{\circ} \mathrm{C}$ and 1,328 $\mathrm{mm}$ of precipitation. The seed used in this research was produced from two commercial single hybrids:
P4285 and 2B587. They were planted in different periods on October 10th and December 5th, respectively. The plots had 4 rows with 3.5 meters and line spacing of $0.90 \mathrm{~m}$. The density planted was 5.67 seeds per meter. The open pollination created the second generation (F2) of P4285 and 2B587.

\subsection{Treatments}

The eight treatments were determined by the days of harvest after pollination (DAP). The pollination was determined in the field when $50 \%$ of the plants showed silk. Harvesting started at 40 days after pollination (DAP) with intervals of 4 days. Thus, the treatments were 40, 44, 48, 52, 56, 60, 64, 68 DAP.

\subsection{Tests Performed}

The milk line was measured using 5 ears collected from corn plants at the middle of the plot. Six seeds were then collected from the middle of which ear. The rate was determined according to the rate proposed by Hunter [1]:

$1=$ Endosperm is entirely liquid; no milk line is visible.

$2=25 \%$ of the seed's length is filled with solidified endosperm.

$3=50 \%$ of endosperm is solid.

$4=75 \%$ of the seed's length contains solidified endosperm.

$5=$ Endosperm is completely solid.

The same seeds evaluated for the milk line were cut in half vertically through the embryo and classified the black layer (Fig. 1) in 5 stages proposed by Rench [3] and modified by Hunter [1] following these stages:

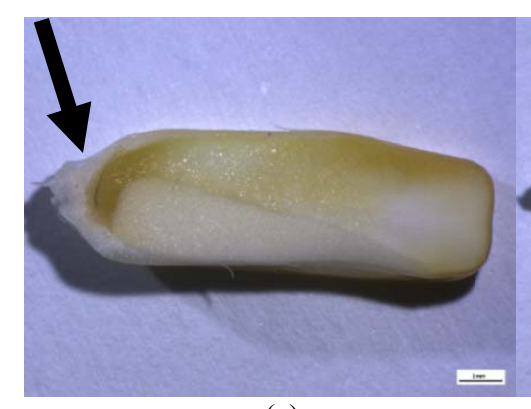

(a)

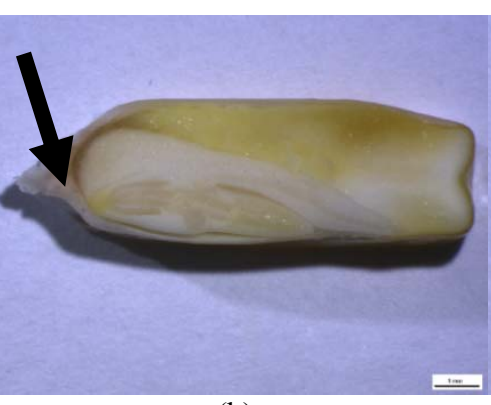

(b)

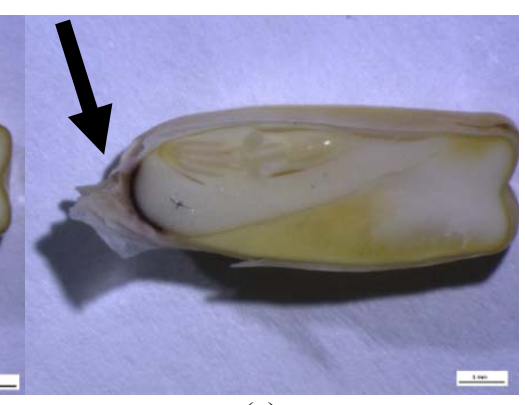

(c)

Fig. 1 Corn seeds in different black layer stages, (a) stage 3, (b) stage 4 and (c) stage 5. 
$1=$ No pigmentation of the basal endosperm or tissue adjacent to the pedicel placental region has occurred; the tissue has a translucent appearance.

$2=$ The region between the embryo and the pedicel-placental region has a translucent appearance and is becoming brown or olive-grey, with darker bands or zones sometimes occurring adjacent to the embryo and/or the pedicel-placental region.

3 = The tissue between the embryo base and the pedicel-placental region is thinner and darker than stage 2 .

$4=$ A thin dark brown band reaches across the entire base of the kernel.

5 = Black layer development is complete: a thin black layer extends across the entire base of the kernel.

The same 5 ears collected and used to identify the milk line and black layer were used to test the endosperm by the tetrazolium salt method, electrophoresis, water content, dry matter and germination test.

To evaluate the activity in the endosperm by tetrazolium salt, 4 replications of 50 seeds were used. The seeds were cut longitudinally through the embryo and immersed in aqueous solution $0.075 \%$ of tetrazolium salt for two hours at $40{ }^{\circ} \mathrm{C}[17,18]$. After the procedure, the seeds were evaluated by coloration in the pedicel-placental and basal endosperm. The results of the coloration were expressed in percentage of seeds with alive endosperm (SEA).

The enzyme activity was also analyzed using one sample of 10 seeds from each treatment. The seeds were soaked in the presence of the antioxidant PVP and liquid nitrogen. Then, protein was extracted using a buffer of potassium phosphate $100 \mathrm{mM}(\mathrm{pH} 7.5)+1$ $\mathrm{mM}$ ethylenediaminetetraacetic acid (EDTA) $+3 \mathrm{mM}$ DL-Ditiotreitol (DTT) in the proportion 3:1 (buffer/fresh weight). The homogenization followed by centrifugation at $10,000 \mathrm{rpm}$ for 30 minutes at $4{ }^{\circ} \mathrm{C}$. The concentration of total proteins was determined with BSA (bovine serum albumin) as is standard, and spectrophotometry at $595 \mathrm{~nm}$ [19]. The electrophoretic technique was performed in polyacrylamide gels system at $12 \%$ (separating gel) and 5\% (concentrating gel). In each band of the gel 40 $\mathrm{g}$ of protein was applied. The gel/electrode system used was Tris-glycine pH 8.3 addicted of $20 \%$ solution $192 \mathrm{mM}$ of glycine at $5{ }^{\circ} \mathrm{C}$ in constant current $20 \mathrm{~mA} \cdot \mathrm{gel}^{-1}$. Gel was developed for enzyme catalase [20]. For the isoenzymes expression, visual analysis of the expression bands was performed.

The water content was determined by drying 4 replications of 50 seeds at $105{ }^{\circ} \mathrm{C} \pm 3{ }^{\circ} \mathrm{C}$ for 24 hours [18], and the results were expressed in percentage of water. The seed dry matter (DM) obtained was divided by 50 to identify the average of dry matter for each seed.

The germination test used 4 replications of 50 seeds put in paper with water content $2.5 \times$ the fresh paper weight, then placed in the germinator at $25{ }^{\circ} \mathrm{C}$ and evaluated on the 4th and 7 th days, for results were expressed in percentage of normal seedling [18].

At the same time, 15 more ears were harvested and dried to procedure for the germination test, aging accelerated and cold test. The harvested ears were put in a heater at $35{ }^{\circ} \mathrm{C}$ until $25 \%$ water content and then at $41{ }^{\circ} \mathrm{C}$ until $12 \%$ water content. Hand threshed followed.

The germination test occurred the same way as mentioned before but now with dry seeds instead of seeds with high water content.

The aging accelerated test occurred with 4 replications of 50 seeds put in plastic boxes $(11 \mathrm{~cm} \times$ $11 \mathrm{~cm} \times 3 \mathrm{~cm}$ ) above aluminum tile and with $40 \mathrm{~mL}$ of distillated water, put in a chamber at $41{ }^{\circ} \mathrm{C}$ for 72 hours. This was followed by a germination test and the results were given in percentage of normal seedlings.

The cold test was realized with 4 replications of 50 seeds in rolled towels moistened with $2.5 \times$ fresh weight paper and incubated for 7 days at $10{ }^{\circ} \mathrm{C}$ and then 4 days at $25{ }^{\circ} \mathrm{C}$. The results were given in 
percentage of normal seedling [21].

\subsection{Statistical Design}

In the field a randomized blocks design was used with 6 blocks and 8 treatments each, in the moment when the harvest determined the water content, milk line, black layer, dry matter, enzyme electrophorese and the tetrazolium salt test. To evaluate the seed quality (germination test, aging accelerated, cold test) the seeds were homogenized and the tests were performed in a completely randomized design with 4 replications of 50 seeds. The data were processed by SAS $^{\circledR}$ statistical software and the means were submitted to Fisher test. The means with significant variance were compared by Tukey test with 0.95 of confidence.

\section{Results and Discussion}

The maximum dry matter was found at 56 DAP for
P4285 (F2) with $308 \mathrm{mg} \cdot \mathrm{seed}^{-1}$, and 52 DAP for 2B587 (F2) with $267 \mathrm{mg} \cdot \mathrm{seed}^{-1}$ (Table 1).

The seed water content declined during the process of maturation, decreasing to $41.0 \%$ for $26.6 \%$ for P4285 (F2) and $40.4 \%$ to $20.2 \%$ for 2 B587 (F2). The water content in the seed at the moment of PM was $32.1 \%$ for P4284 (F2) and 31.2\% for 2B587 (F2).

The regression analysis between dry matter (DM) and days after pollination (DAP) shows a quadratic relationship (Fig. 2) $\mathrm{r}^{2}=0.66$ for P4285 (F2) and $\mathrm{r}^{2}=$ 0.41 for $2 \mathrm{~B} 587$ (F2), this analysis has an accumulation of dry matter over physiological maturity (PM).

The milk line at stage 4, shows the physiological maturity (PM) for P4285 (F2) and 2B587 (F2) at 56 DAP and 48 DAP, respectively (Fig. 3). In addition, the black line was in stage 4 at 52 DAP for both.

When the harvest samples of seeds were put in the germination test with water content (GTMS) after the first four harvests for P4285 (F2), they showed low

Table 1 Corn seeds, genotypes P4285 (F2) and 2B587 (F2) results of: water content (WC), germination test with moist seed (GTMS) and after the drying (GTD), aging accelerated test (AA), seed with endosperm alive (SEA), dry matter (DM), black layer (BL) and milk line (ML).

\begin{tabular}{|c|c|c|c|c|c|c|c|c|c|c|c|c|c|c|}
\hline & \multicolumn{14}{|c|}{ P4285 (F2) } \\
\hline & $\mathrm{WC}$ & GTMS & & GTD & & AA & & $\mathrm{CT}$ & & SEA & $\mathrm{DM}$ & & $\mathrm{BL}$ & $\mathrm{ML}$ \\
\hline DAP & $\%$ & & & & & & & & & & $\mathrm{mg}$ & & & \\
\hline 40 & 41.0 & 0 & $\mathrm{a}$ & 99 & $\mathrm{a}$ & 94 & $\mathrm{~b}$ & 99 & $\mathrm{a}$ & 100 & 254 & $\mathrm{f}$ & 1 & 1 \\
\hline 44 & 39.3 & 1 & $\mathrm{~b}$ & 99 & $\mathrm{a}$ & 94 & b & 99 & $\mathrm{a}$ & 100 & 269 & $\mathrm{e}$ & 2 & 2 \\
\hline 48 & 36.7 & 14 & $\mathrm{c}$ & 98 & $\mathrm{a}$ & 98 & $\mathrm{a}$ & 99 & $\mathrm{a}$ & 98.17 & 296 & $\mathrm{~d}$ & 3 & 3 \\
\hline 52 & 34.8 & 17 & $\mathrm{c}$ & 100 & $\mathrm{a}$ & 96 & $\mathrm{ab}$ & 98 & $\mathrm{a}$ & 79.33 & 302 & $\mathrm{~cd}$ & 4 & 4 \\
\hline 56 & 32.1 & 35 & $\mathrm{~d}$ & 99 & $\mathrm{a}$ & 98 & $\mathrm{a}$ & 99 & $\mathrm{a}$ & 10.67 & 308 & $\mathrm{abc}$ & 5 & 4 \\
\hline 60 & 31.5 & 53 & $\mathrm{e}$ & 99 & $\mathrm{a}$ & 96 & $\mathrm{ab}$ & 98 & $\mathrm{a}$ & 2.75 & 313 & $\mathrm{ab}$ & 5 & 5 \\
\hline 64 & 29.1 & 73 & $\mathrm{f}$ & 99 & $\mathrm{a}$ & 98 & $\mathrm{a}$ & 99 & $\mathrm{a}$ & 0.08 & 320 & $\mathrm{a}$ & 5 & 5 \\
\hline 68 & 26.6 & 88 & $\mathrm{~g}$ & 98 & $\mathrm{a}$ & 99 & $\mathrm{a}$ & 98 & $\mathrm{a}$ & 0.00 & 298 & $\mathrm{~d}$ & 5 & 5 \\
\hline \multirow[t]{2}{*}{$\mathrm{CV} \%$} & & 4.21 & & 0.72 & & 1.80 & & 1.99 & & & 3.27 & & & \\
\hline & \multicolumn{14}{|c|}{ 2B587 (F2) } \\
\hline 40 & 40.4 & 68 & $\mathrm{~b}$ & 98 & $\mathrm{a}$ & 99 & $\mathrm{a}$ & 98 & $\mathrm{a}$ & 100 & 232 & $\mathrm{~d}$ & 3 & 3 \\
\hline 44 & 38.3 & 72 & $\mathrm{~b}$ & 99 & $\mathrm{a}$ & 98 & $\mathrm{a}$ & 99 & $\mathrm{a}$ & 96,7 & 245 & $\mathrm{c}$ & 4 & 3 \\
\hline 48 & 35.2 & 90 & $\mathrm{a}$ & 98 & $\mathrm{a}$ & 95 & $\mathrm{ab}$ & 98 & $\mathrm{ab}$ & 89,33 & 248 & $\mathrm{c}$ & 4 & 4 \\
\hline 52 & 31.2 & 98 & $\mathrm{a}$ & 98 & $\mathrm{a}$ & 92 & $\mathrm{ab}$ & 89 & $\mathrm{ab}$ & 75,08 & 267 & $\mathrm{ab}$ & 4 & 5 \\
\hline 56 & 29.6 & 98 & $\mathrm{a}$ & 98 & $\mathrm{a}$ & 95 & $\mathrm{ab}$ & 91 & $\mathrm{ab}$ & 19,58 & 260 & $\mathrm{~b}$ & 5 & 5 \\
\hline 60 & 28.6 & 97 & $\mathrm{a}$ & 91 & $\mathrm{ab}$ & 90 & $\mathrm{ab}$ & 90 & $\mathrm{ab}$ & 4,25 & 270 & $\mathrm{a}$ & 5 & 5 \\
\hline 64 & 23.8 & 95 & $\mathrm{a}$ & 92 & $a b$ & 87 & $\mathrm{~b}$ & 89 & $a b$ & 0,08 & 267 & $\mathrm{ab}$ & 5 & 5 \\
\hline 68 & 20.2 & 88 & $\mathrm{a}$ & 90 & $\mathrm{~b}$ & 85 & $\mathrm{~b}$ & 86 & $\mathrm{~b}$ & 0,00 & 261 & $\mathrm{~b}$ & 5 & 5 \\
\hline $\mathrm{CV} \%$ & & 7.29 & & 4.86 & & 6.09 & & 5.41 & & & 3.70 & & & \\
\hline
\end{tabular}

* Averages with the same letter do not have statistical difference by Tukey test $p \leq 0.05$. 

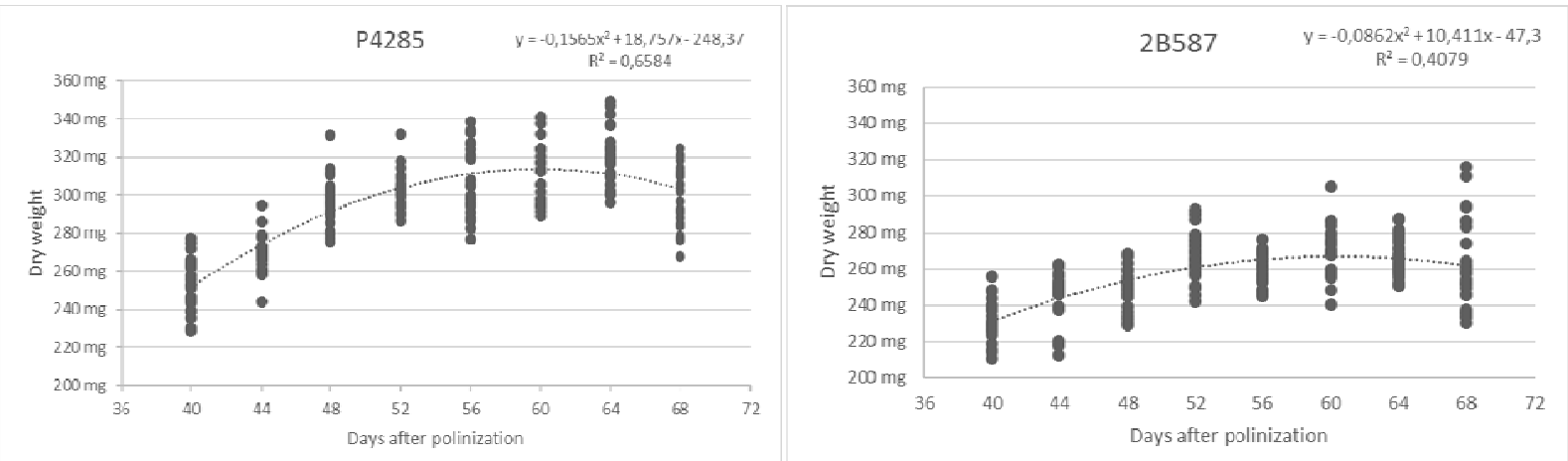

Fig. 2 Dry matter regression analysis.
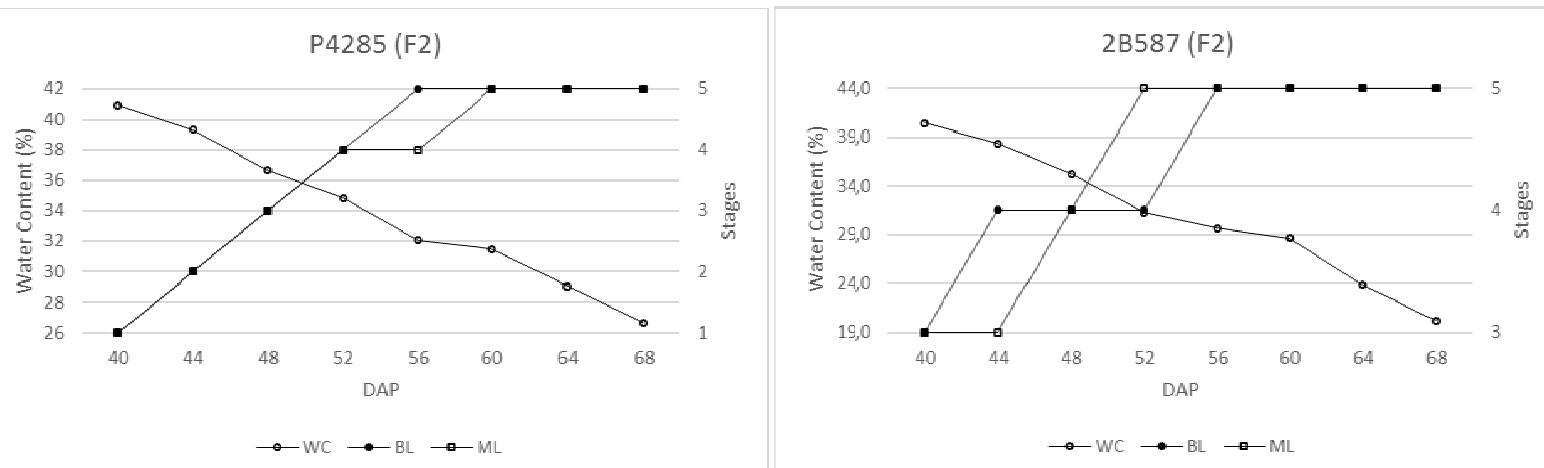

Fig. 3 Behavior of water content (WC), black layer (BL) and milk line (ML) in relation of treatments of P4285 (F2) and 2B587 (F2).

germinations; $0,1,14$ and $17 \%$. The two first harvests for $2 \mathrm{~B} 587$ (F2) showed $68 \%$ and $72 \%$ germination. However, in the germination tests with dry seeds (GTDS) in the same period, the germination improved to $99,99,98$ and $100 \%$ for P4285 (F2) and 98 and $99 \%$ for 2B587 (F2).

The accelerated aging test (AA) was used as one indicator to test the seeds under stress conditions and evaluate the vigor. The best germination for P4285 (F2) was at 48 DAP with $98 \%$, and for 2B587 (F2) was at 40 DAP with $99 \%$. Furthermore, this test indicated a decrease for 2B587 (F2) starting at 64 DAP to 68 DAP showing 87 and $85 \%$ respectively (Fig. 4).

The cold test (CT) was another indicator of seed vigor and showed the greatest level for P4285 (F2) and 2B587 (F2) at 40 DAP with 99 and 98\%, respectively. 2B587 (F2) showed a decline in vigor at 68 DAP.

Complementing with the data presented, the tetrazolium salt method was used to monitor the cell activity of the endosperm, especially in the basal region, Fig. 5. If the seed had activity in the endosperm it was counted as a seed with endosperm alive (SEA). When the rate was under $50 \%$ it was possible to assume that most parts of the seeds were at the physiological maturity point. This occurred at 56 DAP for both materials evaluated.

The catalase enzyme is responsible to avoid the oxidation and deterioration of embryo tissues. So, the activity of this enzyme means the correct operation of the system and the survival of the seed by itself. To complement the data presented about PM the electrophoresis was realized for catalase enzyme. The increase of activity this enzyme occurred after 56 DAP for P4285 (F2) (Fig. 6), and for 2B587 (F2) at 56 DAP (Fig. 7).

\section{Discussion}

The purpose of this research was to develop a 


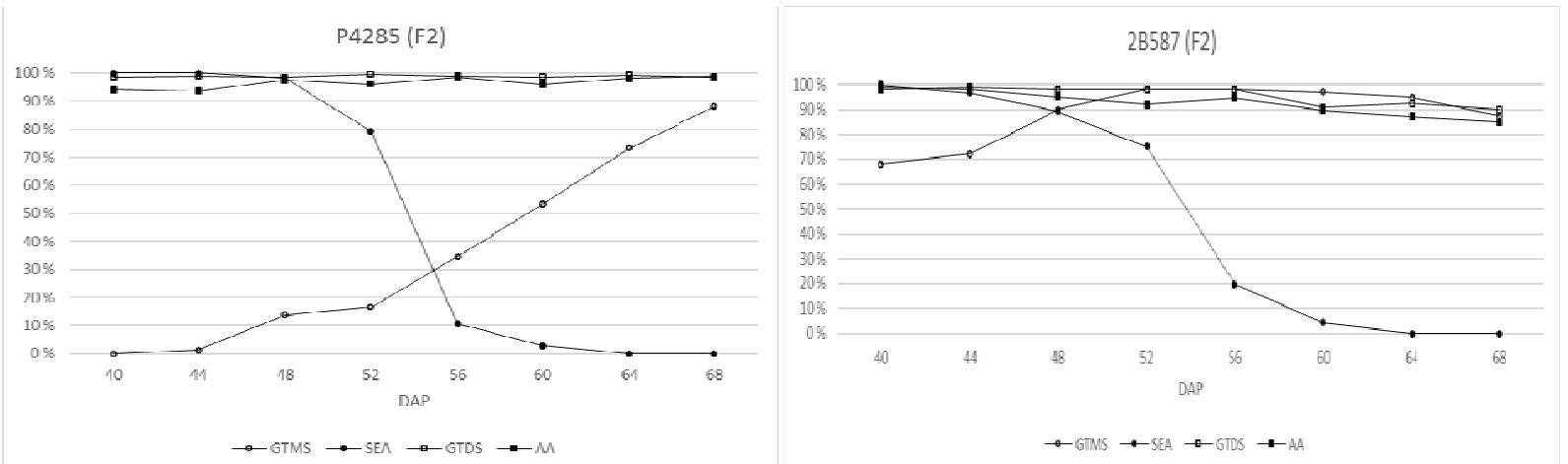

Fig. 4 Comparsion of germination test with seed (GTMS), seeds with endosperm alive (SEA), germination test of dry seed (GTDS) and aging accelerated (AA) of P4285 (F2) and 2B587 (F2).

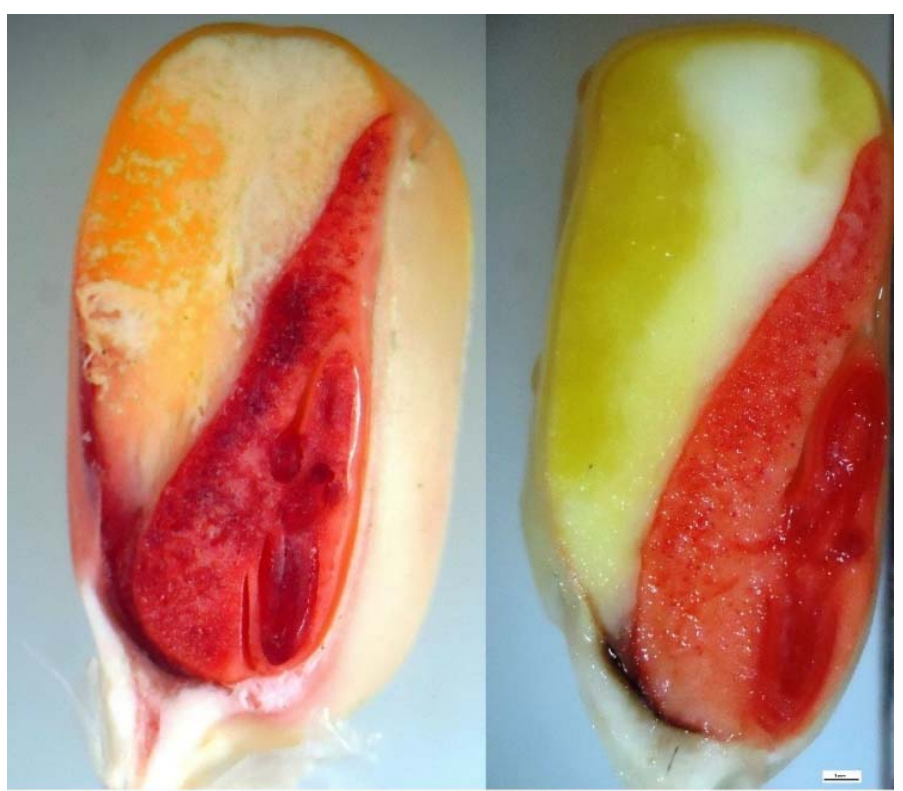

Fig. 5 Corn seeds treated with tetrazolium salt.

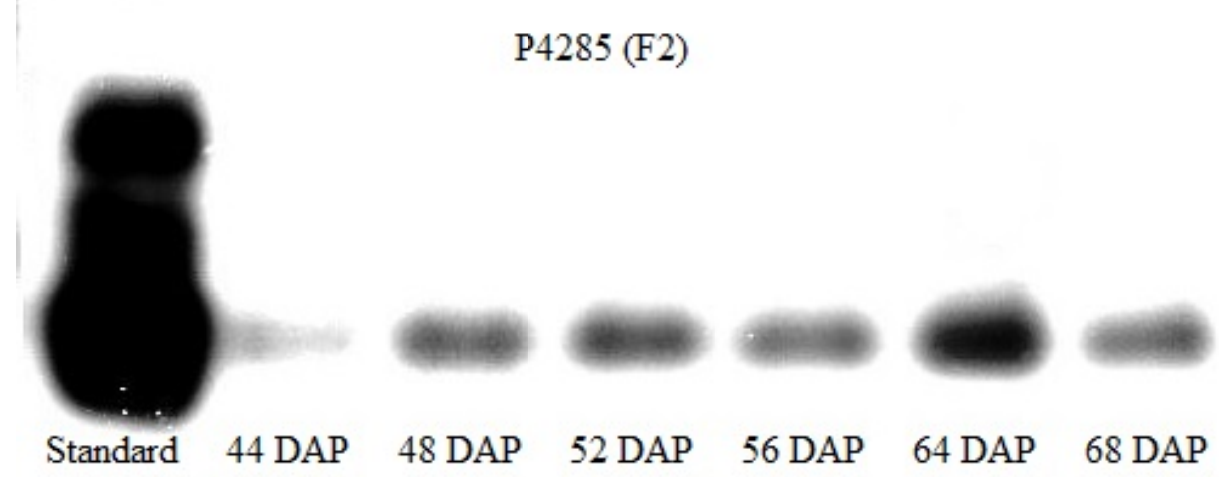

Fig. 6 Catalase electrophoresis of corn seeds of P4285 (F2). 


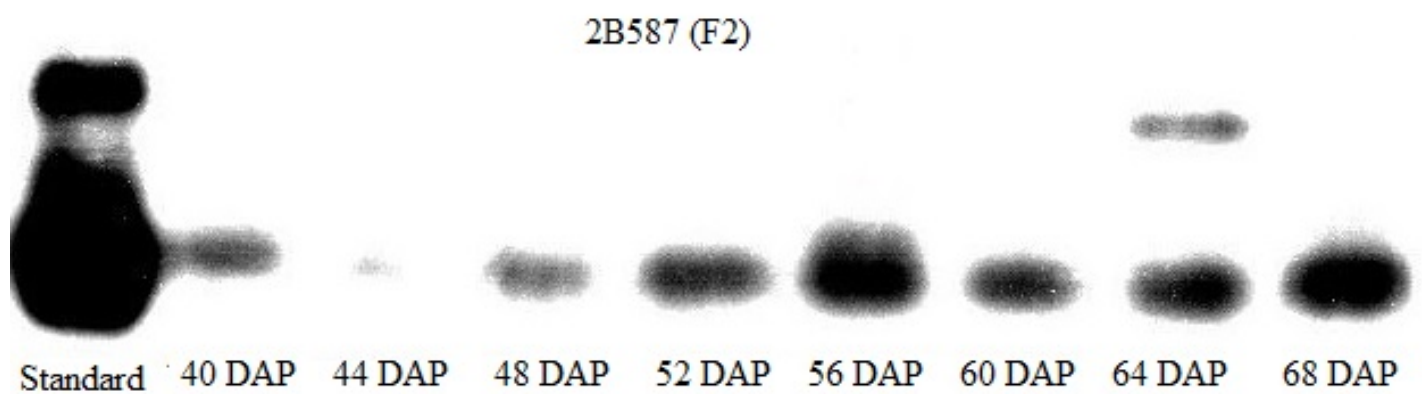

Fig. 7 Catalase electrophoresis of corn seeds of 2B587 (F2).

trustworthy method to correlate the activity of tetrazolium salt in the endosperm tissue with the other indicators; ML, BL and DM. After conducting research, the tetrazolium salt showed a good performance and correlated with $\mathrm{DM}, \mathrm{ML}$ and $\mathrm{BL}$ positively. The rating was $r^{2}=0.63, r^{2}=0.80$ and $r^{2}=$ 0.90 respectively of P4285 (F2). In complement, for the 2B587 (F2) it was $r^{2}=0.91, r^{2}=0.91$ and $r^{2}=$ 0.88 .

The DM showed an increase and then a stabilization at the PM. This data is supported by many other authors, but the problem with this parameter is that it is impossible to predict the harvest time until this point is achieved [3, 6, 9, 22].

The black layer was found to be independent of the kind of genotype or the year cultivated [4-8]. For the two materials evaluated in this study, the black layer developed consistently with the reports mentioned before. Both materials completed the formation of the black layer at 56 DAP.

In addition, the milk line (ML) determines stage 4 to be the ideal in identifying the PM [1]. This showed P4285 (F2) consolidated at 56 DAP and the 2B587 (F2) at 48 DAP.

Furthermore, black layer and milk line had a positive correlation: $r^{2}=0.95$ of $\mathrm{P} 4285$ (F2) and $\mathrm{r}^{2}=$ 0.74 of 2B587 (F2). The ML and the dry matter (DM) for P4285 (F2) and 2B587 (F2) had a positive correlation: $r^{2}=0.91$ and $r^{2}=0.86$, respectively. For the BL and DM: $\mathrm{r}^{2}=0.91$ and 0.76 . Therefore, these three components are connected to determine the physiological maturity.
Over several years, extensive research with inbred, single hybrids, double hybrids and varieties concludes that $\mathrm{BL}$ and $\mathrm{ML}$ are correlated to $\mathrm{PM}$ and the maximum germination and vigor of the seeds [11]. In this way, both materials evaluated were found to have maximum vigor by the aging accelerated test at 48 DAP with $98 \%$ of germination for P4285 (F2) and at 40 DAP and $99 \%$ of germination for 2B587 (F2). In addition, the maximum germination was achieved at 40 DAP for both.

Additionally, investigation conducted in Brazil [23] confirmed the maximum quality of the seeds of single hybrids harvested at stage 4 in the ML.

It is also possible to find the PM of P4285 (F2) at 56 DAP where the DM was at the maximum, the $\mathrm{BL}$ at stage 5 , and the ML at stage 4 . The tetrazolium method indicated $89.03 \%$ with no activity in the endosperm. The 2B587 (F2) achieved the maximum $\mathrm{DM}$ at $52 \mathrm{DAP}$, the BL stage 4 at $52 \mathrm{DAP}$, the ML at stage 4 at 48 DAP, and the tetrazolium method showed at 56 DAP $80.42 \%$ with no activity in the endosperm. Thus, the PM was found to be between 48 and 56 DAP.

To confirm this data, the electrophoresis showed an improvement of the catalase activity after 56 DAP for the P4285 (F2) and at 56 DAP for the 2B587 (F2).

Both materials presented maximum vigor and germination before PM. The P4285 (F2) achieved maximum vigor 8 days before $\mathrm{PM}$ and 16 days before the best germination. With the 2B587, the PM averaged between 48 and $56 \mathrm{DAP}$, so at $52 \mathrm{DAP}$, the maximum vigor and germination was found 12 days 
prior.

Therefore, the identification of PM gives the opportunity to harvest the seed at the right moment for highest quality. In both cases, it was shown that maximum vigor and germination was achieved before the PM. It is possible to anticipate the harvest date to guarantee quality. Knowing when to harvest material at its highest quality saves money by reducing product loss from water content damage and disease, and less days are spent in the fields. In addition, the material 2B587 (F2) demonstrated the effect of delay on harvest. For this genotype, the first harvesting showed high quality and best performance. In the late periods of harvest, a reduction in the germination test and vigor test (Fig. 4), was shown caused by diseases.

\section{Conclusion}

The tetrazolium salt is efficient to identify physiological maturity of corn seeds and has positive correlation with other evaluations as: black layer, milk line and maximum dry matter.

\section{Acknowledgements}

Grant \#2014/13851-1, Sao Paulo Research Foundation (FAPESP). And the Laboratory of Plant Biochemical Genetics part of the Genetics Department, Escola Superior de Agricultura "Luiz de Queiroz", University of Sao Paulo.

\section{References}

[1] Afuakwa, J. J., and Crookston, R. K. 1984. "Using the Kernel Milk Line to Visually Monitor Grain Maturity in Maize." Crop Science 24 (4): 687-91.

[2] Afuakwa, J. J., Crookston, R. K., and Jones, R. J. 1984. "Effect of Temperature and Sucrose Availability on Kernel Black Layer Development in Maize." Crop Science 24 (2): 285-8.

[3] Alupei, M. C., Licarete, E., Cristian, F. B., and Banciu, M. 2014. "Cytotoxicity of Lipophilic Statins Depends on Their Combined Actions on HIF-1 Alpha Expression and Redox Status in B16.F10 Melanoma Cells.” Anti-Cancer Drugs 25 (4): 393-405.

[4] Barros, A. S. D. R., Dias, M. C. L. D. L., Cicero, S. M., and Krzyzanowski, F. C. 1999. "Testes de Frio.” In Vigor de sementes conceitos e testes, edited by Krzyzanowski, F. C., Vieria, R. D. and França Neto, J. D. B. Londrina: Londrina ABRATES.

[5] Brasil, agropecuária, S. D. D. 2009. Regras para análise de sementes. Brasília: Ministério da Agricultura, Pecuária e Abastecimento.

[6] Couto, A. A. 2006. Eletroforese e marcadores bioquímicos em plantas e microrganismos (2nd ed.). Viçosa: UFV.

[7] Carter, M. W., and Poneleit, C. G. 1973. "Black Layer Maturity and Filling Period Variation among Inbred Lines of Corn (Zea-mays L.)." Crop Science 13 (4): 436-9.

[8] Chamma, H. M. C. P., and Novembre, A. D. D. L. C. 2007. "Teste de tetrazólio para as sementes de milho: períodos de hidratação e de coloração das sementes." Revista Brasileira de Sementes 29: 125-9.

[9] Copeland, L. O., and McDonald, M. 2001. Principles of Seed Science and Technology (4th ed.). Boston: Springer US.

[10] Daynard, T. B. 1972. "Relationships among Black Layer Formation, Grain Water Content Percentage, and Heat unit Accumulation in Corn." Agronomy Journal 64 (6): 716.

[11] Daynard, T. B., and Duncan, W. G. 1969 "Black Layer and Grain Maturity in Corn." Crop Science 9 (4): 473.

[12] Hunter, J. L., Tekrony, D. M., Miles, D. F., and Egli, D. B. 1991. "Corn Seed Maturity Indicators and Their Relationship to Uptake of c-14 Assimilate." Crop Science 31 (5): 1309-13.

[13] Jacob, E. A., Mertz, L. M., Henning, F. A., Peske, S. T., Villela, F. A., and Labbe, L. M. B. 2014. "Ideal Seeds Harvest Moment of Different Maize Hybrids." Ciencia Rural 44 (2): 253-60.

[14] Lakon, G. 1940. "The Topographical Selenium Method, a New Method for the Establishment of Viability of Cereal Seed without a Growth Test." In Proceedings of the International Seed Testing Association. Copenhagen: ISTA, pp. 1-18.

[15] Bradford, M. M. 1976. "A Rapid and Sensitive Method for the Quantitation of Microgram Quantities of Protein Utilizing the Principle of Protein-Dye-Binding." Analytical Biochemistry 72 (1-2): 248-59.

[16] Moore, R. P. 1985. Handbook on Tetrazolium Test. Zurich: International Seed Testing Association.

[17] Popinigis, F. 1977. Fisiologia de Sementes.Brasília: Agiplan.

[18] Rench, W. E., and Shaw, R. H. 1971. "Black Layer Development in Corn." Agronomy Journal 63 (2): 303.

[19] Shaw, R. H., and Thom, H. C. S. 1951. "On the Phenology of Field Corn, Silking to Maturity." Agronomy Journal 43 (11): 541-6. 
[20] Sutton, L. M., and Stucker, R. E. 1974. "Growing Degree Days to Black Layer Compared to Minnesota Relative Maturity Rating of Corn Hybrids." Crop Science 14 (3): 408-12.

[21] Tekrony, D. M., and Hunter, J. L. 1995. "Effect of Seed Maturation and Genotype on Seed Vigor in Maize." Crop Science 35 (3): 857-62.
[22] Vieira, R. D., Minohara, L., Carvalho, N. M. D., and Bergamaschi, M. C. M. 1995. "Relationship of Black Layer and Milk Line Development on Maize Seed Maturity." Scientia Agricola 52: 142-7.

[23] Yu, X.-R., Zhou, L., Xiong, F., and Wang, Z. 2014. "Structural and Histochemical Characterization of Developing Rice Caryopsis.” Rice Science 21 (3): 142-9. 